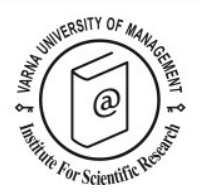

\title{
The Sponsorship Motive Matrix (SMM): A Framework for Categorising Firms' Motives for Sponsoring Sports Events
}

\author{
Terje Slåtten ${ }^{1 *}$, Göran Svensson ${ }^{2}$, Steven Connolley ${ }^{3}$, \\ Cathrine Bexrud ${ }^{1}$ and Tone Lægreid ${ }^{1}$
}

Received: 15/05/2015 Accepted: 19/07/2016

\footnotetext{
1 Faculty of Economics and Organizational Sciences, Lillehammer University College, 2604 Lillehammer, Norway

${ }^{2}$ Professor, Kristiania University College, Oslo, Norway

${ }^{3}$ Doctoral student, Lillehammer University College, 2604 Lillehammer, Norway; e-mail: steven.connolley@hil.no

* Corresponding author: tel: 004792040 829; e-mail: Terje.Slatten@hil.no
}

\begin{abstract}
Though there is a large body of literature and research on sponsorship of sports events, it seems that previous research on firm sponsorship of sports events has narrowly focused on sponsorship from a customer perspective. Consequently, research on sponsorship from a firm perspective is lacking. Specifically, it seems that no study has investigated and identified the main factors that motivate the sponsorship of sports events. This article begins with exploring firms' motives for sponsorship found in the literature, and identifies two fundamental pairs of contrastive orientations related to sponsorship motives: internal versus external motives and opportunistic versus altruistic motives. Next, we combine the four fundamental motivational orientations into a two-way matrix that constitutes a framework for categorising firms' motivations for sponsoring sports events. We also explore and elaborate the framework more fully in a qualitative study. On the basis of empirical findings, we identify four general or ideal types of motivational categories that reflect the combination of firms' fundamental and contrastive orientations related to sponsorship motives. The main or ideal types of sponsorship motivational categories are labelled "market", "society", "bond" and "clan". The final framework, displaying firms' four main categories or ideal types of sponsorship motives, is referred to as the Sponsorship Motive Matrix (SMM). We conclude with suggestions for future research and a discussion of the implications that can be drawn from the SMM framework.
\end{abstract}

(C) 2017 Varna University of Management. All rights reserved

Keywords: Event, Sponsorship, Business firms, Sport, Sponsor Motive Matrix (SMM).

Citation: Slåtten, T., G. Svensson, S. Connolley, C. Bexrud and T. Lægreid (2017) The Sponsorship Motive Matrix (SMM): A Framework for Categorising Firms' Motives for Sponsoring Sports Events. European Journal of Tourism Research 15, pp. 143-166

Introduction

Sponsorship is one of the most rapidly growing areas of modern marketing (Delia and Armstrong, 2015). According to figures from
Sponsorship Outlook in 2013, more than 53.3 billion dollars were spent on sponsorship worldwide (www.Sponsorship.com). One important reason for this growth in sponsorship 
The Sponsorship Motive Matrix (SMM): A Framework for Categorising Firms' Motives for Sponsoring Sports Events.

seems to be that traditional marketing channels such as television, radio and magazine advertisements are becoming less effective than others, including sponsorship. Clearly, it is important to understand motives to the decision to sponsor (Smith et al., 2016).

Consequently, an increasing number of firms see sponsorship as a natural and important part of their marketing mix. As a result, sponsorship for some firms constitutes the largest proportion of their total budget for marketing communication. For example, in Norway, sponsorship has become the thirdlargest communication channel (Thjømøe, 2010). In line with this, Alexandris et al. (2012) state that sponsorship may be a more effective communication strategy than traditional advertising. Moreover, Helgesen (2004) observes that the primary goal of sponsorship is to strengthen companies' market positions on the long run. Clearly, sponsorship is a powerful medium for communicating and forming relationships with a specific target group (Bowdin et al., 2011; Collett and Fenton, 2011).

In recent years, there has been a growth in the number of firms that sponsor events. Today, many events have sponsors, and these occasions give firms opportunities to make their business visible to many spectators. Consequently, firms find event sponsorship to be a powerful forum in which to communicate and build their brands (Thjømøe, 2010). In addition, it is not surprising that event sponsorship is one of the most common sources of funding for performance events. Indeed, events are becoming increasingly dependent on sponsorship.

Sponsorship has been defined as the "provision of assistance, either financial or in kind, to an activity by a commercial organization for the purpose of achieving commercial objectives" (Meenaghan, 1983). A review of sponsorship reveals that most previous studies have to a large extent focused on firm sponsorship in relationship to external outcome variables. These outcome variables have generally been restricted to aspects related to customers.
Specifically, most research has focused on how and in what way sponsorship is able to form relationships with a firm's customers, and the extent to which it directly or indirectly affects the firm's sales. In a review of the literature by Madill and O'Reilly (2010) the authors reveal more than 50 objectives related to sponsorships. Moreover, previous research has found that sponsorship has a positive impact on return on investment (ROI) (e.g., Harvey, 2001) and influences customers' awareness, firm image, goodwill and recall recognition of the sponsor (Nielsen, 1990; Rifon et al., 2004) and achievement of media exposure (Crompton, 2004). Sponsorship has also been linked to corporate social responsibility (CSR) (e.g., Plewa and Quester, 2011). Sponsorship affects customers' brand loyalty (Sirgy et al., 2008) and attitudes towards an event (Bhat, 2012). It also increases customers' intentions to purchase the sponsor's product (Ngan et al., 2011), and sponsorship of particular events has a positive impact on effectiveness of sponsorship in general (see Alexandris et al., 2012; Cornwell et al., 2006; Gwinner and Bennett, 2008; Miloch and Lambrecht, 2006; Kotler and Keller, 2009; Slåtten et al., 2014a; Skinner and Rukavina, 2003; Walraven et al., 2012).

This review reveals that previous research on firm sponsorship has primarily taken a customer perspective focused on external outcome variables related to a target group (e.g., firm sales or image). Although this is clearly a critical area of research, it also reveals that research that takes an organisational perspective has generally been neglected. For example, we have little knowledge about what we refer to (in the manner of popular science) as the general nature of "sponsorship-motive DNA" of the fundamental elements and dynamics of sponsorship motives that actually prompt firms to sponsor a sports event. Following this line of reasoning, Madill and O'Reilly (2010) state, “... no theory has been formulated on the nature and type of objectives commonly associated with different types of sponsorships" (p. 134). Cleary, it is important to increase our knowledge and insight related to this aspect of sponsorship. 
"Traditionally, sponsorship is used most extensively in the sport sector", Madill and O'Reilly observe (2010: 63). Moreover, according to Bouchet et al., (2015: 200) "Corporate sponsorship plays an increasingly crucial role in sports...". Although it seems clear that firm sponsorship is most often used in the sports sector and has an important role here, it seems that our knowledge and insight connected to the reasons and fundamental motives of why firms actually join in sponsorship remain elusive. On this topic, Shank (2009: 464) states, "The primary motivation for an organisation participating in sport sponsorships is still unclear." In a similar vein, Apostolopoulou and Papadimitriou (2004: 182) state, "There has been limited research focusing on the reasons companies decide to become involved in sport". In a recent article by Slåtten et al. (2014a), the authors' state: "There is ... a need for more thorough research identifying possible motives for a firm's decisions about sponsorship" (p. 232). The need for more research examining firms' motives for sponsorship is thus manifest. Accordingly, the objective of this study is to explore and describe firms' general categories of motives associated with sports sponsorship. More precisely, the present study explores the following research question: What are the categories of firm's motives for sponsoring sports events?

According to Madhill and O'Reilly (2010: 134) the "development concerning sponsorship is at an early stage of development". Moreover, Plewa and Quester (2011: 304) state that, "Sport remains the primary focus of sponsorship globally, with over two-thirds of all sponsorship activities related to sport". This article contributes in two ways to the body of literature on sports sponsorship. First, through a firm perspective, our study broadens the theory and our understanding and identification of the main categories of motives for sponsoring sports events. To the authors' knowledge this is the first study that has sought to contribute to the knowledge in this area of sponsorship research. Secondly, on the basis of a literature review and empirical findings related to sponsorship motives, this study identifies the practical factors of sponsorship programmes that firms' managers as well as event managers must consider when planning to meet each other's expectations and when cooperating to develop appropriate sponsorship strategies and tactics. By enhancing our knowledge and insights about firms' motives for sports sponsorship, this study makes a significant step towards the goal of what Kotler and Keller (2009: 561) describe as "designing the optimal sponsorship program" and facing the challenge that Cornwall and Kwak (2015: 133) present: "How is it possible to work with [sponsorship] partners for the best outcomes for all involved partners?"

This article begins with a review and discussion of the perspectives on the motives generally emphasised in the mainstream sponsorship literature and in practice. Secondly, on the basis of this literature review, we propose a framework for categorising sponsorship motives. Next, this article presents an empirical study that has applied this framework in order to test it. This article ends with managerial implications and suggestions for future research connected to the proposed conceptual framework.

\section{Literature review}

\section{Sponsorship objectives}

The literature contains limited research on firms' motives for sponsorship. It seems that what has been written is rather fragmented, often with the inclusion of lists of possible firm objectives for being sponsors. One example is Skinner and Rukavina (2003), who in their book suggest a range of firm sponsorship objectives such as increased visibility, enhancement of reputation, creating enthusiasm among employees, creating marketing opportunities, differentiating a product from those of competitors and running promotions. Another example is Collett and Fenton (2011), who present a variety of objectives such as awareness of the brand, motivation of employees, community relations, increasing sales and development of staff competence.

Similarly, Shank (2009) presents nine different and general objectives for firms' choosing to be sponsors. Motives for sponsorship were related to public demonstrations of social responsibility, changing customers' perceptions of the company, increasing sales, improving 
The Sponsorship Motive Matrix (SMM): A Framework for Categorising Firms' Motives for Sponsoring Sports Events.

relationships with partners as well as creating goodwill, improving employees' relationship with the company and improving the company's reputation. In contrast to Shank (2009), Zinger and O'Reilly (2010), examined sponsorship objectives from a small business perspective. Using a case methodological approach, the authors identified totally six sponsorship objectives, namely: community goodwill, ability to cultivate awareness of the firm, employee relations, identifiable commercial objectives and personal preferences of owner impact on the decision.

In a study by Séguin et al., (2005: 72) the authors mention the results from a comprehensive literature review focusing on corporate objectives of sponsorship. By referring to numerous studies, they identify a broad range of sponsorship objectives mentioned in the literature: corporate awareness, corporate image, corporate perception, brand promotions, sales, raising involvement with the local community, building trade relations, enhancing employee relations and motivation, blocking competition, reaching target market and so on. This literature review suggests that there are good reasons to conclude that corporate objectives to an overwhelming degree are dominated by an external focus and specifically in some or another way are related (indirect or directly) to the customer sphere.

One of the very few empirical studies on firms' objectives for sponsorship is Apostolopoulou and Papadimitriou's (2004). In their qualitative study, the authors interviewed seven of the 10 Grand National Olympic sponsors of the Athens 2004 Olympic Games. The results reveal that objectives for the sponsors were related to goals such as increasing sales, enhancing the image of the company, increasing brand awareness, being involved in the community, and improving employee relations. In an recent study, Greenhalgh and Greenwell (2013) identify a total of seven sponsorship objectives: (i) increasing public corporate awareness, (ii) enhancing corporate image, (iii) altering public perception, (iv) getting involved in the community, (v) building business-trade goodwill, (vi) enhancing employee relations and motivation, (vii) increasing target-market awareness and (viii) increasing sales and market share. The empirical study of the seven objectives used reveal that corporate firms especially emphasised awareness, company image and enhanced community involvement as the most important. Though there were different objectives, what six of the seven identified objectives have in common is that they have an outward or external focus on sponsorship.

Consequently, as the discussion above reveals, the literature suggests a variety of objectives for firms to enter sponsorship relationships. However, it seems that most previous studies of corporate objectives share a dominant emphasis on the outward or external focus (i.e., customers as the target group). Next section takes a deeper look at how sponsorship are described in the literature.

\section{Descriptions of sponsorship in the literature}

To achieve a deeper understanding and a more systematic view of sponsorship from a firm perspective, it is necessary to examine two fundamental factors related to sponsorship: (i) the ways that the literature in general defines or describes sponsorship, and (ii) the identification of the focus emphasised in these characterisations of sponsorship.

Table 1 illustrates 15 examples of descriptions identified through a literature review. All the statements in Table 1 represent descriptions from different point of view, such as (i) empirical studies, (ii) theoretical scientific articles, (iii) current practices and (iv) popular scientific sources about sponsorship. Table 1 thus provides a broad overview of the characteristics and content of sponsorship as described in the literature, and the fundamental emphases and focuses that underpin descriptions represented in the literature about sponsorship.

Table 1 reveals that we may draw two main conclusions on the basis of existing definitions in the literature concerning the characteristics of sponsorship. First, it reveals that there is a broad diversity in descriptions of content in the construct of sponsorship. For example, J. A. Meenaghan (1983) emphasises in his definition that sponsorship is a "provision of assistance 
... to an activity". Moreover, Jiffer and Roos (1999) label sponsorship as a "business method for communication". In contrast to these two definitions, Sleight (1989) and Skinner and Rukavina (2003) both suggest that sponsorship is about building relationships while Rifon et al. (2004) stress that sponsorship should "influence [a target] audience" as a result of firms' engagement in sponsorship. Secondly, with respect to the specific focus of the definitions, the table reveals a relatively high degree of consensus in the literature in that the goal of sponsorship should be linked to some specific benefit or value.

Table 1. Focuses of descriptions of sponsorship in the literature

\begin{tabular}{|c|c|c|}
\hline Author(s) & Description of sponsorship & $\begin{array}{l}\text { Focus in the } \\
\text { description }\end{array}$ \\
\hline $\begin{array}{l}\text { Meenaghan } \\
(1983)\end{array}$ & $\begin{array}{l}\text { Provision of assistance, either financial or in-kind, to an activity by a } \\
\text { commercial organization for the purpose of achieving commercial } \\
\text { objectives. }\end{array}$ & External focus \\
\hline $\begin{array}{l}\text { Meenaghan } \\
(1991)\end{array}$ & $\begin{array}{l}\text { An investment, in cash or in kind, in an activity, person, or event, in } \\
\text { return for access to the exploitable commercial potential associated } \\
\text { with that activity, person, or event by the investor. }\end{array}$ & External focus \\
\hline Sleight (1989) & $\begin{array}{l}\text { Business relationship between of funds, resources, or services and an } \\
\text { individual, event or organization which offers in return some rights } \\
\text { and association that may be used for commercial advantage. }\end{array}$ & External focus \\
\hline $\begin{array}{l}\text { Cornwell and } \\
\text { Maignan (1998) }\end{array}$ & $\begin{array}{l}\text { The company promotes its interests and brands by linking them to a } \\
\text { specific and meaningful event or cause. The sponsor also actively } \\
\text { markets his association with the sponsored event or cause. }\end{array}$ & $\begin{array}{l}\text { Nonspecific } \\
\text { focus }\end{array}$ \\
\hline $\begin{array}{l}\text { Jiffer and Roos } \\
\text { (1999) }\end{array}$ & $\begin{array}{l}\text { A business method for communication and marketing, which in the short } \\
\text { and long term has the aim of contributing to the sponsor's brand } \\
\text { awareness and image, as well as increasing the sponsor's sales. } \\
\text { Sponsorship should benefit all those involved and should lead to a } \\
\text { result that can be measured against predefined objectives. }\end{array}$ & $\begin{array}{l}\text { Mostly external } \\
\text { focus (touch on } \\
\text { internal focus) }\end{array}$ \\
\hline $\begin{array}{l}\text { Skinner and } \\
\text { Rukavina (2003) }\end{array}$ & $\begin{array}{l}\text { An activity that puts buyers and sellers together, with both receiving } \\
\text { certain benefits. }\end{array}$ & External focus \\
\hline $\begin{array}{l}\text { Mullin, Hardy and } \\
\text { Sutton (2000) }\end{array}$ & $\begin{array}{l}\text { The acquisition or rights to affiliate or to associate directly with a product } \\
\text { or an event for the purpose of deriving benefits related to that } \\
\text { affiliation or association. }\end{array}$ & $\begin{array}{l}\text { Mostly external } \\
\text { focus (touch on } \\
\text { internal focus) }\end{array}$ \\
\hline $\begin{array}{l}\text { Collett and Fenton } \\
\text { (2011) }\end{array}$ & $\begin{array}{l}\text { Sponsorship is an associative marketing tool that creates mutual brand } \\
\text { and business value for both the sponsor and the sponsored activity. }\end{array}$ & External focus \\
\hline $\begin{array}{l}\text { International } \\
\text { Chamber of } \\
\text { Commerce (ICC) }\end{array}$ & $\begin{array}{l}\text { Any commercial agreement by which a sponsor, for the mutual benefit of } \\
\text { the sponsor and sponsored party, contractually provides financing or } \\
\text { other support in order to establish an association between the }\end{array}$ & $\begin{array}{l}\text { Mostly external } \\
\text { focus (touch on } \\
\text { internal focus) }\end{array}$ \\
\hline $\begin{array}{l}\text { International Code } \\
\text { on Sponsorship } \\
(2003)\end{array}$ & $\begin{array}{l}\text { return for rights to promote this association and/or for the granting of } \\
\text { certain agreed direct or indirect benefits. }\end{array}$ & \\
\hline $\begin{array}{l}\text { Gardner and } \\
\text { Shuman (1988) }\end{array}$ & $\begin{array}{l}\text { Investments in causes or events to support corporate objectives (for } \\
\text { example, by enhancing corporate image) or marketing objectives } \\
\text { (such as increasing brand awareness). }\end{array}$ & External focus \\
\hline Cornwell (1995) & $\begin{array}{l}\text { The orchestration and implementation of marketing activities for the } \\
\text { purpose of building and communicating an association to a } \\
\text { sponsorship. }\end{array}$ & $\begin{array}{l}\text { Nonspecific } \\
\text { focus }\end{array}$ \\
\hline McAllisterm (1998) & $\begin{array}{l}\text { The funding of an entire event, group, broadcast or place by on } \\
\text { commercial interest in exchange for large amounts and special types } \\
\text { of promotion connected with the sponsored activity }\end{array}$ & $\begin{array}{l}\text { Mostly an } \\
\text { external focus }\end{array}$ \\
\hline Rifon et al. (2004) & $\begin{array}{l}\text { Corporation (or other investor) creates a link with an outside issue or } \\
\text { event, hoping to influence the audience by the connection" }\end{array}$ & External focus \\
\hline $\begin{array}{l}\text { Sandler and Shani } \\
\text { (1989) }\end{array}$ & $\begin{array}{l}\text { The provision of resources (e.g., money, people, equipment) by an } \\
\text { organization directly to an event or activity in exchange for a direct } \\
\text { association to the event or activity. The providing organization can } \\
\text { then use this direct association to achieve either their corporate } \\
\text { market or media objectives }\end{array}$ & $\begin{array}{l}\text { Mostly an } \\
\text { external focus }\end{array}$ \\
\hline Cameron (2009) & $\begin{array}{l}\text { Sponsorship involves a three-way communication process in which the } \\
\text { consumer views the brand message together with the property in a } \\
\text { "passion" mode }\end{array}$ & External focus \\
\hline
\end{tabular}


The Sponsorship Motive Matrix (SMM): A Framework for Categorising Firms' Motives for Sponsoring Sports Events.

Table 1 reveals that nine of a total of 15 descriptions explicitly suggest that sponsorship should result in some form of commercial benefit or achieve an objective for the firms (e.g., increased sales, brand awareness and image), or both. Consequently, it is perhaps not surprising that all definitions in Table 1 seem to have a narrow emphasis on externally focused motives for sponsorship.

With externally focused motives, firms strive towards goals and objectives beyond the sponsorship organisation (e.g., existing or potential new customers). A good example of this is Skinner and Rukavina's (2003) definition that accentuates sponsorship as the building of relationships between buyer and seller. Clearly, their way of describing sponsorship emphasises that firms' decisions to sponsor are rooted in an outward focus and motives linked to firms' customers.

\section{External versus internal motives of a firm's sponsorship}

On the basis of findings in Table 1 and the discussion above, we can see that the literature has to a great extent a narrow emphasis on external focus and motives for sponsorship. Most often, the descriptions of sponsorship in one way or another relate to firms' present or potential customers. Of the 15 definitions and descriptions listed in Table 1, 11 in total emphasise an external focus of sponsorship motives. These external motives can, for example, relate to firm customers, stakeholders and partners, the creation of perceptions of image, quality and value, and the building of loyalty among these (external) groups. Table 1 implies that external motives should be considered as one general and fundamental kind of sponsorship motives.

Clearly, focusing on external motives is natural and important when a firm decides whether or not to sponsor a sports event. However, it is also reasonable to assume that there are other motives than just externally focused motives for actually participating in sponsorship programmes. Though not explicitly mentioned in Table 1, there is good reason to assume that internal (firm) conditions could also be linked to motives and decisions about participating in sponsorship. For example, it is reasonable to assume that some sponsorship motives could involve or target groups related to the firms' inner life. In contrast to externally focused motives, this motivational category can referred to "internally focused motives".

The 15 descriptions in Table 1 reveal that none of these clearly and explicitly mentions internally focused motives as a part of their descriptions of sponsorship. However, some definitions and descriptions in Table 1 "hint" at other focuses and motives than only external motives for firm sponsorship. Three of the 15 descriptions obliquely suggest the notion that there could be internally focused motives for sponsorship. One example is the descriptions put forth by Mullin et al., (2000) who refer to sponsorship as, "The acquisition or rights to affiliate......for the purpose of deriving benefits related to that affiliation or association". These authors' statement, using the word "benefit", could be interpreted to include the advantages and value of the sponsorship that are not limited to externally related motives: they can also include internal motives of sponsorship and thus constitute a separate category of sponsorship motives.

These internal motives could be related to firms' use of sponsorship to build pride, motivation and commitment to the firm among its employees, cooperative partners, stakeholders and others. This kind of sponsorship motive may be a part of an internal marketing tactic, or part of a strategy or programme. The sponsorship literature offers support that there are internally focused motives for sponsorship. For example, Walraven et al. (2012) state that, "sponsorships, when used as an internal branding vehicle, have a potential to contribute to employees' identification and commitment with the corporate brand, their level of company pride and ultimately loyalty" (p. 29). Moreover, Zinger and O'Reilly (2010) found in their case study that employee relations were one motive for firms sponsorship. Similarly, Hickman et al. (2005) point out that, "Anecdotal evidence suggest that firms recognize that sponsorship of sports can potentially influence employee...". Clearly, in addition to external motives there is support that internal motives could be another general category of sponsorship motives. 
As the discussion above reveals, a firm's motives for sponsorship can be classified as either (i) external or (ii) internal, depending on which of the two categories are reflected in the underlying goals. However, the common factor of external and internal motives is that they both represent "areas" where the benefit of sponsorship should be achieved.

Opportunistic versus altruistic motives of firms' sponsorship

In addition to the distinction between externally and internally focused motives, there is another motivational contrast that is both relevant and important to consider. Specifically, this difference emphasises who is mainly meant to benefit from the firm's participation in sports sponsorship: those external to the firm or those internal to the firm. This contrast is also parallel to the difference between emotional and rational motives for sponsorship. Arthur et al. (1997) suggest that firms' decision-making processes about sponsorship can be labelled as either (i) rational or (ii) emotional. Thus, besides the internal and external "areas" discussed above, this study raises another motivational contrast that captures firms' considerations and decisions focusing on "who or what" should benefit or take advantage from the sponsorship. It is reasonable to assume that this is an important motivational dimension. Similarly and parallel to internal and external motives, rational versus emotional can be understood as representing two contrasting orientations of sponsorship motives.

Specifically, this study understands and describes rational motives as those that are directed towards goals solely to enrich the company somehow. The primary motivation for sponsorship is driven purely by egoism, selfinterest and opportunism. This study uses "opportunism" as the label that represents the rational motive of sponsorship. Opportunism corresponds with what Williamson (1975) defines as "self-interest seeking with guile" ( $p$. 6 ). It is reasonable to assume that opportunism can vary in intensity and strength. Examples of opportunistic motives could be a firm's focus on increased sales, brand awareness, ROI or media exposure. Such opportunistic motives are directed to clear commercial intentions, objectives and outcomes.
As already indicated, in contrast to rational motives, there are what this study calls "emotional" motives. Emotional motives are focused on and directed towards wider-ranging or broader goals other than those solely concerning the enrichment of the company itself commercially. The underlying nature of a company's emotional motives for sponsorship can be described in terms related to unselfishness, self-sacrifice or altruism. This study employs the label of "altruism" to represent emotional motives. Altruism is associated with sympathy, friendship and socialisation (Okasha, 2005). In business it is strongly associated with corporate giving or philanthropy (Polonsky and Speed, 2001) and what Plewa and Quester (2011: 301) refer to as charitable giving that "entails ... little or no expectation of return. Moreover, in contrast to opportunistic motives, altruistic motives embrace what Thomas Nagel (1970: 79) describes as a "... willingness to act in the consideration of interest of other...... without the need of the ulterior motives". Schulze et al. (2002: 252) state, "At the extreme, altruism ... is a moral value that motivates individuals to undertake actions that benefit others without any expectation of external reward". Clearly, in its purest, loftiest sense, altruistic motives are highly idealistic and visionary. However, considering the quotidian worldly realities of business life in general, it is difficult to imagine a firm acting altruistically in absolute terms, but it is sensible to assume that firms normally can act altruistically in qualified ways. It is more realistic to claim that firms can act in an altruistic-like manner. Examples of altruistic motives include decisions to participate in sponsorship because it is ethically, normative and morally correct to do so, founded on a desire to be a part of a good and responsible citizenry or to support the local community without any expectations or beliefs related to profitmaking outcomes.

Consequently, we argue that a firm's underlying motive for sponsorship can be categorised as either (i) opportunistic or (ii) altruistic. However, unlike the previous categorisation of external versus internal sponsorship motives, which represent "areas" were the benefits of sponsorship should be achieved, a common factor of opportunistic and 
The Sponsorship Motive Matrix (SMM): A Framework for Categorising Firms' Motives for Sponsoring Sports Events.

altruistic motives is that they both represent "who or what" should benefit or take advantage from the sponsorship. It is important to note that none of these four motives (internal, external, opportunistic or altruistic) points to any form of explicit specific sponsorship objectives or goal (e.g., increasing a firm's brand awareness). Consequently, the four motives constitute the fundamental orientations of firms' motives for sponsoring sports events.

In summary, on the basis of the discussion above, we can make sense of the motivations for firm sponsorship by locating them according to the two contrasting motivational spectrums, arranged as a two-way matrix. First, sponsorship motives can be categorised as either internal or external, reflecting "areas" in which the benefit of sponsorship should be achieved. Secondly, sponsorship motives can be categorised as either opportunistic or altruistic, reflecting "who or what" should benefit from the sponsorship. Additionally, we combine the two contrasting motivational directions identified in the previous discussion. This combination is illustrated in figure 1.

Figure 1 illustrates the two-way matrix combining the two contrastive motivational continuums. The vertical $(\mathrm{Y})$ axis is a continuum of sponsorship motives ranging from internal to external (reflecting "areas" where the benefit of sponsorship is supposed to take place). The horizontal (X) axis shows a continuum of sponsorship motives ranging from opportunistic to altruistic (reflecting "who or what" should benefit from the sponsorship). As shown in figure 1, the merging the two motivational continuums forms four cells reflecting potential different categories or ideal types of firms' overall sponsorship motives.

Consequently, this study uses the framework in Figure 1 as empirical tool to explore and describe with the aim to take a further step of abstraction to identify categories or ideal types of firm's motives for sponsoring sport events.

\section{Methodology}

The objective of this study is to identify and describe categories of firms' motives for sponsoring sports events. Events are occasions, gatherings or activities that differ from people's everyday activities (Shone and Parry, 2004; Bowdin et al., 2011). This study used two winter sports events as a basis for the choice of sponsors. The two sports events were the Birkebeiner Race and Skarverennet. Both of these are ski races located in the south of Norway and can be characterised as "mega sport events". Specifically, both ski races (i) attract a large number of people who attend the events and (ii) attract a diversity of firms that sponsor them.

We expended considerable time and effort to find informants representing the heterogeneity of firms sponsoring these sports events. By including a variety of types of firms, we were able to employ a data-collection strategy that would identify a variety of motives for sponsoring the sports events.

To avoid including too many firms with an obvious match between their products and the sports event (e.g., selling ski wax or sports

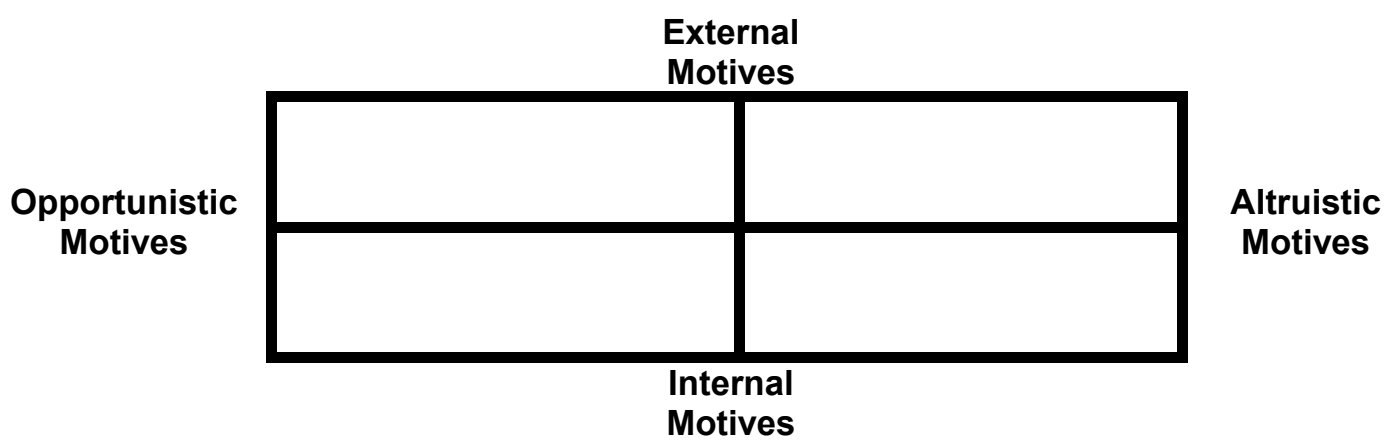

Figure 1. Firms' Contrasting Motivational Directions for Sponsorship 
equipment), we decided to divide the chosen firms into two categories. All firms were categorised as having either a "natural" or "non-natural" linkage with the event that they sponsored. Consequently, this study used a purposeful sampling strategy (Bickman and Rog, 1998). We used both a focus group and assessments by one expert in the field of sponsorship as guiding "tools" for sorting the firms into the two categories. In total, eight informants representing eight firms were included.

Each informants in each of the eight firms was chosen on the basis of their position in the firm relative to the specific sponsorship of these sports events. All informants had been involved in and were knowledgeable about the decisionmaking process and the motives that led to the sponsorship of the event. They were all responsible for the sponsorship as part of their position and work tasks. All respondents were thus key informants concerning the phenomenon that is the focus of this study.
Table 2 gives an overview of the type of firm, position and gender of each informant, along with the degree of match between the sports event and the firm sponsoring it. It is reasonable to assume that the selection of informants and the choice of sports events overall constitute a satisfactory empirical basis in view of the objective and research questions of the study.

This study used a semi-structured interview guide. This interview method often gives the informant the opportunity to "determine what route" to follow during the interview, from start to finish answering questions from the researcher. As the goal was to acquire an indepth understanding of motives for sponsoring sports events, we found that it was best to let the informants communicate in their own terms and manner as much as possible (Silverman, 2000).

Each interview lasted from one half to one-anda-half hours. Some main topics discussed were (i) the criteria for choosing what to sponsor, (ii)

Table 2. Profile of key informants included in the empirical study

\begin{tabular}{lll}
\hline Type of firm & Informant & Gender \\
\hline Sells ski wax* & Director of sponsorship & Male \\
Sells winter sports equipment* & Sales manager & Male \\
Sells sports equipment* & Marketing manager & Male \\
Sells sports equipment* & Director of sports & Male \\
Sells cars ** & PR manager & Male \\
Sells building materials** & Key account manager & Male \\
Sells cars** & Marketing consultant & Female \\
State-owned enterprise** & Marketing manager & Female \\
\hline
\end{tabular}

Notes: *Natural linkage between the firm's product and the sports event; ${ }^{* *}$ Non-natural linkage between the firm's product and the sports event.

Table 3. Motives identified in the empirical study

\begin{tabular}{|c|c|c|c|c|}
\hline Type of firm & Market & Society & Clan & Bond \\
\hline Sells ski wax* & $\mathrm{X}$ & $x$ & $x$ & \\
\hline Sells sports equipment* & $X$ & & & $x$ \\
\hline Sells sports equipment* & $X$ & $x$ & & \\
\hline Sells sports equipment* & X & & & \\
\hline Sells cars** & $X$ & & $x$ & \\
\hline Sells building materials** & & & $x$ & $X$ \\
\hline Sells cars ${ }^{* *}$ & $X$ & $x$ & $x$ & $x$ \\
\hline State-owned enterprise** & & $X$ & $x$ & $x$ \\
\hline
\end{tabular}

Notes: *Natural linkage between the firm's product and the sports event; ${ }^{\star \star}$ Non-natural linkage between the firm's product and the sports event 
The Sponsorship Motive Matrix (SMM): A Framework for Categorising Firms' Motives for Sponsoring Sports Events.

the fundamental motives for sponsorship and (iii) the goals and value of sponsorship.

This study employed the framework in Figure 1 as a guide for the interviews and as a way of categorising the findings. Thus, the connection between empirical research, concepts and theory can be described as emergent (Bryman, 1988).

The analysis of the interviews involved an interpretation of meaning (Kvale and Brinkmann, 2009), guided by the framework in Figure 1. In a further step of abstraction to explore and elaborate the framework in figure 1 more fully three steps were undertaken: (i) an initial grouping of the interviews based on regularities, (ii) analysis of meaningful relationships between interview data to identify motivational categories, and, (iii) labelling categories or ideal types of sponsorship motives. Consequently, the quotations are empirical illustrations of specific categories or ideal types of firm's sponsorship motives that emerged from the interviews.

\section{Findings and Discussion}

Table 3 summarises the findings on firms' motives for sponsoring sports events.

There are two aspects of Table 3 that should be noted. First, and maybe most interesting, four domain or ideal types of categories emerged in the findings based on theoretical framework in Figure 1. As seen in the heading in table 3 these categories or ideal types are labelled "Market," "Society," "Clan" and "Bond". Second, most informants pointed to several motives for sponsoring an sport event. However, in most cases were one motive clearly predominating. These predominated motives can be describes the primary or fundamental motive for a firm's decision to sponsor a sports event. Moreover, motives that did not dominate can be labelled as secondary or peripheral motives for sponsorship. Table 3 indicates the primary or fundamental sponsorship motive for each of the eight firm with a bold uppercase $X$. The secondary or peripheral motives are marked with a lowercase $x$ in regular font. In the following section, the findings from the empirical study related to each of the four motivational categories ("Market", "Society", "Bond" and "Clan") are outlined in more detail.

\section{Market motive}

The market motives in Table 3 point to the underlying goals of enhancing sales among existing customers or potential new customers. Totally six informants mentioned that their primary motive for sponsoring a sports event related directly to one or more firm goal(s) and the opportunity to gain some sort of (competitive) advantage or generate increased sales. Specifically, most of the fundamental firm motives for sponsorship linked to a combination of external and opportunistic motives, centred on goals concerning a specific target group.

Consequently, according to the Figure 2, and shown in Table 3, the market motive was the most common and was clearly the leading and dominating motive for sponsoring an event. This finding is supported by previous research. For example Séguin et al., (2005: 72), referring to Shank (2001) state that the "... objective for nearly all organisations involved in sponsorship programmes is an increase in sales". Of the eight firm representatives interviewed, six emphasised the market motive as the primary or fundamental motive for engaging in sponsorship. One of the informants illustrated this point with the following statement:

"We believe that sponsorship participation through events will help generate increased sales."

This example illustrates that most firms use sponsorship as a strategy to promote goals related to increased sales. Previous research has identified the sponsorship of sports events as one way to do this (Apostolopoulou and Papadimitriou, 2004; Davis and Tsiantas, 2008).

However, with regard to firms' expectations of how the sponsorship will generate sales, the findings indicate a distinction based on whether there is a natural or non-natural linkage between a product and a sports event. Firms with a natural linkage sell products that are substitutes for, or supplementary or 
complementary to, the products used in the sports event.

Two of the informants noted that their firms actually sell their products during the event to both participants and spectators. Consequently, because of the high degree of correspondence between the firm and the sponsored event, firms consider sponsorship to be a direct route to the goal of selling their products.

In contrast, firms that have a non-natural linkage to the event have another "route to market logic" or expectations of how their sponsorship can actually achieve the goal of selling the firm's products. In their explanations, these informants suggest an indirect way and a long-term perspective on how sponsorship can or (hopefully) will enhance sales of the firms' products. One informant provided an illustrative example of this logic:

"We do not expect to sell cars during the actual event, but possibly in the aftermath of the event."

Although a firm's products might not have a direct and logical linkage with the sports event, sponsorship can be a marketing strategy in a number of ways. First and most fundamentally, brand building is an essential precondition for customers to acquire knowledge of the brand, and if customers are not aware of the brand, they cannot consider or choose it (Samuelsen et al., 2010). Secondly, sports has much appeal to a very large number of people, and events provide firms with the opportunity to reach a wide audience (Shank, 2009).

Consequently, sports events increase the visibility of both a firm's brand and its products. These points were emphasised during the interviews. The following quotations from the informants exemplify these points of view:

"Sports have managed to develop and build a forum that other (sponsorship beneficiaries) don't have."

"A sports event is nice forum to meet several people at the same time ... that's why we use sponsorship."
"Sports events are more visible in the market than cultural events ... because they attract a lot of media attention."

It is important to ensure that the target group evaluates the sponsorship as positive. One way to ensure this is to sponsor a sports event with the same values and goals as the firm itself. One informant stressed this as follows:

"We mostly sponsor sports events that suit our slogan ... this (event) suits our firm (slogan) very well."

Consequently, if the sponsoring firm and the sports event are not compatible on a concrete (product) level, they should be so on a more abstract (image) level.

\section{Society motive}

According to Figure 2, society motives reflect a combination of firms' external and altruistic company motives for sponsorship. These motives relate to goal(s) that are significantly broader and more general in nature, without any specific consumer or target group for sales in mind.

Of the eight interviewees, four firm representatives mentioned society as one motive for being a sponsor. Three of the four firms mentioned society as a secondary motive. However, one respondent explicitly emphasised the society motive as the primary or fundamental reason for sponsorship (see Table 3). The following quotations illustrate well how the society motive is linked to this firm's decision to sponsor:

"The goal of this sport event is 'everyone is included or invited', improving people's health and getting people outdoors ... this is something our firm will contribute to."

"... If it means something in the local environment, we want to be there."

These quotations show how the sponsor of the sports event gives an unconditional "helping hand" without any specific expectations of return on sponsorship investment (ROSI). 
The Sponsorship Motive Matrix (SMM): A Framework for Categorising Firms' Motives for Sponsoring Sports Events.

Previous research supports these findings. For example, a study by Apostolopoulou and Papadimitriou (2004: 186), focusing on firms' motives for sponsoring the Athens 2004 Olympic Games, have found that one of four motives for firm sponsorship were to "help the country (Greece) in a national effort". Moreover, the authors quote one informant who clearly showed an altruistic motive by stating: "what is important is the intangible benefit and not the financial benefit ... our participation is symbolic" (Apostolopoulou and Papadimitriou, 2004: 187). Clearly, this emphasises the altruistic aspect of the similar society motive found in this study.

Although only one of the four firms in this study mentioned its altruistic motive in its purest form, the other three firms mentioned society motives as a secondary motive for sponsorship. For these firms, their society motive can be described as altruism in its qualified form. These firms did not have any clear or specific expectations for their sponsorship investment. However, the firm representatives commented that if the sponsorship had yielded positive returns, it would (of course) be valued and appreciated. Yet there was no aspiration for such an outcome from their firms' sponsorship engagements. One of the informants stated that their qualified form of altruism was as follows:

"This event is in our eyes a folk festival and is the most stunning adventure during the spring. I hope we manage to ... associate ourselves with a nice (sports) event."

It is not fanciful to assume that firms have some thoughts and ideas about goodwill achieved at some level as a result of their sponsorship. This could be at what $\mathrm{T}$. Meenaghan (2001: 102) labels the "generic level" of goodwill. This goodwill is related to consumers' emotions because of a firm's engagement in actually sponsoring the event.

Consequently, it is reasonable to assume that altruism in its qualified form is the most appropriate way to define the society motive for commercial firms.

\section{Bond motive}

As Figure 2 shows, the bond motive reflects a combination of firms' internal and opportunistic motives for engaging in sponsorship. Specifically, the bond motive prompts firms to use sponsorship as a means of achieving specific goals related to a target group (or groups).

The findings from the interviews reveal that bonding is a relevant firm motive. Of the eight respondents interviewed, four firms emphasised bond motive for sponsoring sports events. Of this one firm considered bond motive as their primary or fundamental motive for sponsoring a sports event (see table 3). Moreover, the bond motive can be divided according to two groups of stakeholders.

The first group is firm collaborators. One of the respondents mentioned bonding with this stakeholder group as the firm's primary motive for engaging in sponsorship as follows:

"The main reason why we sponsor ... is because we want to build stronger relationships with our dealers and partners."

Examining this primary bond motive more closely, we find that the firm uses the time and place of a sports event to promote and achieve a goal linked to building a relationship between the cooperating firms. The informant from this firm emphasised this point as follows:

"It is beneficial for all parties to meet in an environment they do not normally mingle in and do something outside of work. (By this) ... they get the opportunity to talk together, know each other better in an informal situation and get closer to each other in a different way, compared with ... (for example) ... a regular meeting."

Bonding has been suggested as a "core objective" for business success and a key source of completive advantage (Smith, 1998). Previous research has proposed that sponsorship can have a positive effect on a firm's stakeholders. Clark et al. (2003: 139), for example, suggest, "Managers can utilise sport 
sponsorships to develop and enhance relationships at every stage of the relationship cycle".

Firms that invite stakeholders to participate in sponsorship programmes affect stakeholders and earn their gratitude (Walraven et al., 2012). Moreover, because they are grateful for their participation in such a programme; the stakeholders will be more able to engage in reciprocal behaviour and to develop positive feelings towards the inviting firm (e.g., a desire to continue or develop the relationship). According to Palmatier et al. (2009: 2-3), "gratitude is a fundamental social component of human interactions ... and contributes to the ongoing construction of a relationship". This study clearly shows that firms use sponsorship to build relationships with dealers as an important stakeholder group.

The second group of firm stakeholder that the bond motive embraces comprises employees. According to Grönroos (2007), it is a prerequisite for the achievement of common firm goals that employees are satisfied and have a sense of belonging to the company for which they work. Employees are an important stakeholder group with whom firms build bonds.

Two of the three firm representatives mentioned the bond motive as secondary or peripheral for their firms' decisions about sponsorship. Moreover, these people emphasised that firms' engagement in sponsorship has a positive influence on their firms' employees. The following quotations demonstrate this point:

"Primarily, first and foremost, it creates pride in relationships with our brand among employees to see our company logo on TV during the sports event."

“... Sponsorship of this event ... creates ... ownership for our firm and clearly generates a winning culture and creates a great deal of (employee) motivation."

Although there is a small body of literature on this theme, previous research has indicated that firms use sponsorship to create a sense of commitment between the employees and the firm. Firm sponsorship is linked to bond factors such as employee identification with the firm, pride, loyalty, and employee commitment (Rosenberg \& Woods, 1995). Hickman et al. (2005) found a positive effect of sponsorship on employee morale manifested in employees' willingness to satisfy customers. According to Walraven et al. (2012), “... sponsorship on relations with ... stakeholders have not been well documented in previous research."

Consequently, more research is clearly needed in this area. However, this study reveals that firms' decisions about sponsorship can be founded on a bond motive directed towards both firms' stakeholders and employees.

\section{Clan motive}

The final category of fundamental motive for sponsoring sports event in this study is the clan motive as shown in Figure 2. According to the Free Dictionary, a clan is a large group of relatives, friends, or associates. Consequently, a clan is a group of people who are connected in one way or another. Thus, a firm's employees can be described as a clan. Such people are connected through informal and formal networks, and promote the firm's interests.

A clan in this study is the overall network of people working together. Specifically, it concerns how firms use sponsorship to help their employees to have positive experiences and to achieve positive outcomes in their lives.

In Figure 2, the clan motive is exemplified by displays of firms' dedication and expressions of care for employees in general. Goals related to the clan motive are more extensive and broader in their underlying form and focus, compared with those related to the bond motive.

The findings reveal that none of the firm respondents interviewed mentioned the clan motive as a primary one for sponsorship (see table 3). However, five of the eight firms mentioned it as a secondary or peripheral motive for their firms' decisions about sponsorship. Moreover, goals of the clan motive for sponsorship can be divided into 
The Sponsorship Motive Matrix (SMM): A Framework for Categorising Firms' Motives for Sponsoring Sports Events.

types: social and health-related goals. These two goals are sometimes intertwined and can be combined with the firm's role of facilitator and motivator.

The health goal focuses on the general health condition of individual employees in the organisation. The health condition of employees can be identified and measured as a percentage of employees who are sick, which is the number of employees absent divided by the total number of employees. The rate of absence is rooted in symptoms of underlying health problems, caused either by the individual employee's lifestyle or by the working conditions in the enterprise. Whatever the cause, the absentee rate represents a cost for the firm. The firm wishes to help its employees avoiding sickness and continuously seeks to uphold the health of individual employees in the firm as best as it can.

The interviewees who emphasised the clan motive mentioned that firm sponsorship was used as a "tool" to motivate people to be more physically active and to improve the overall health of the employees. In this way, it was a positive contribution both to the individual employee and (hopefully) also to the firm, by reducing absenteeism or enhancing generally more productivity during the working day, or both. Two interviewees highlighted this point:

"To get employees ... trained, one may have to pay training fees. We use thousands of kroner each year to cover membership fees at fitness centres, gyms etc. ... But it is worth it, and repays the cost, as people (in our organisation) are less often sick."

"Companies that allow employees to train both in and outside of working hours will help to ensure that employees feel that they get more profit from the working day."

To motivate people, it is not enough for managers to urge employees regularly to become more active. It may also be necessary to use other incentives, such as paying for the use of fitness equipment or allowing for flexible schedules, such as allowing the employee to spend some of their working time doing physical exercise.

Social goals, related to firms' clan motives, focus on creating a forum where people in the organisations can meet other people. These can be people from the same department or those in other places. Firm sponsorship creates a natural forum at a specific time and place for people to meet socially.

Two of the firms actively use sports events as meeting places or bases where the employees from different departments sleep in the same area and eat together. Those who want to can participate in the ski race. However, to mobilise and motivate as many people as possible, it is necessary for the firm to plan actively, as well as to engage with and to facilitate activities for employees who want to participate in the social events during the sports event. As one informant reported:

"The more one facilitates, the easier it is to get employees actually to participate."

As this discussion has revealed, the clan motive of sponsorship is a firm's expression of dedication and care for employees. This is done by creating a forum, giving the employees the opportunity to socialise with other people while also improving employees' health by encouraging them to do physical exercise regularly. In this way, the employees have something to look forward to, whether it is socialising or participating in a sports event. As one informant concluded in a summary of the clan motive for the firm's sponsorship:

"Employees have something to look forward to, something to train for ... and a motivation to actually train."

Consequently, the firm's clan motives for sponsorship offer the opportunity to achieve two goals at the same time.

In the following section, the two motivational directions are combined to form the foundation of a framework for categorising firm motives for sponsorship. 


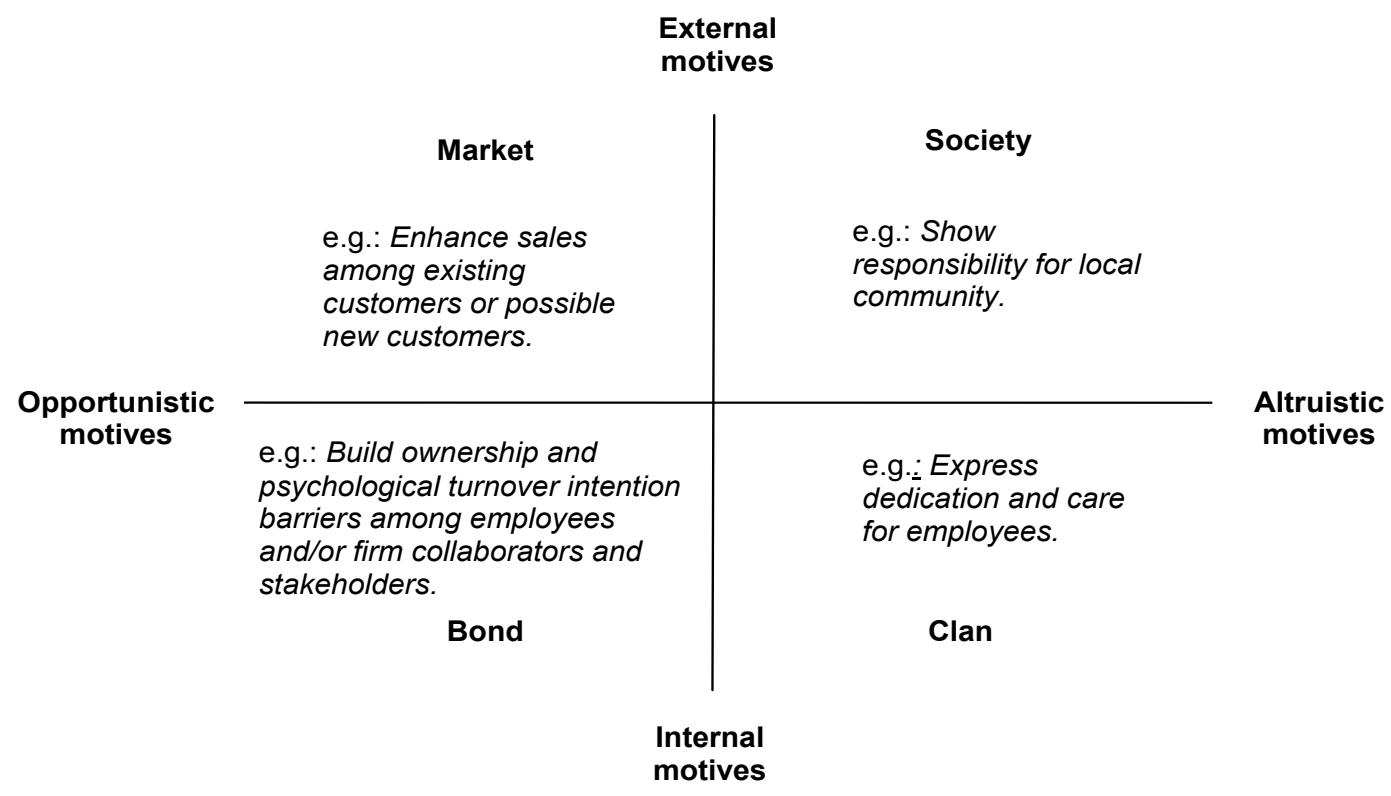

Figure 2. Sponsorship Motive Matrix (SMM)

\section{Research implications}

Figure 2 shows an important research implication from empirical findings. Specifically, based on empirical findings, four categories or ideal types' sponsorship motives was identified. These four motivational categories reflect the combination of firms' fundamental and contrastive orientations related to sponsorship motives identified in the literature review (see also figure 1). In figure 2 these four cells, (i) market, (ii) society, (iii) bond and (iv) clan, represent focuses and goals that reflecting the underlying combination of firms' motives for sponsorship. Examples of goals stemming from each of the four combinations of motives are given in the figure 2. Consequently, Figure 2 illustrates sponsorship motives when combining the literature review with the empirical study undertaken. The framework, showing the four motivational categories of ideal types, may be referred to as the Sponsorship Motive Matrix (SMM).

Figure 2 shows that "market" and "society" are both related to external motives for being a sponsor. In contrast, "bond" and "clan" are both related to a firm's internal motives. "Markef" is centred on goals related to a specific target group, whereas "society" signifies more general goals and focuses less on a specific target group for sponsorship. In Figure 2, "market" is exemplified by goals related to the enhancement of sales among existing customers or possible new customers and is a combination of firms' external and opportunistic motives. In contrast, goals related to "society" are a combination of external and altruistic motives to engage in sponsorship. In Figure 2, these are exemplified by the use of sponsorship as a way to demonstrate a responsible attitude towards the local community.

Figure 2 shows that "bond" and "clan" are both related to internal motives. Internal motives relate to the organisation's resources (e.g., employees) and the resources to maintain the organisation (e.g., a firm's co-operators and partners). Depending on whether the firm's internal motive is concurrent with an opportunistic or altruistic motive, it can be labelled as either "bond" or "clan," which represents two categories of internal motives. Parallel to the firm's focus or goals mentioned above ("market" and "society"), "bond" is centred on specific goals and means to an end, 
The Sponsorship Motive Matrix (SMM): A Framework for Categorising Firms' Motives for Sponsoring Sports Events.

related to a target group (e.g., employees, cooperators). In contrast, "Clan" motives are broader, and goals related to clan motives are more extensive in their underlying form and focus in relation to a target group. In Figure 2, "clan" motives are exemplified by a desire to express dedication to and care for a firm's employees. In contrast, "bond" motives related to a specific target group; these are exemplified in Figure 2 as underlying goals related to building ownership and psychological barriers to turnover intention among employees or firm collaborators and stakeholders, or all of these.

It is important to note that these types of focus or goals in the SMM, labelled "market," "society," "bond," and "clan" in Figure 2, are all modal or dominant rather than mutually exclusive. Following this line of reasoning, most firms can and do have elements of several types of goals reflecting the different combinations of motives for sponsorship. However, it is reasonable to assume that one type of focus or goal emerges as dominant in the long term, while others are less so. Following this line of reasoning, there will be variations in sponsorship motives among firms.

Consequently, based on findings from the empirical study summarized in table 3 and figure 2, it is reasonable to assume that each firm will have what can be described as a sponsorship motive profile indicating its primary or dominating motive (e.g., a market motive) and (often) followed by a secondary sponsorship motive (e.g., a clan motive).

\section{Practical implications}

Smith et al. (2016:2) state that, "given the increasing importance of sponsorship, there is a need to understand the decision to sponsor". The main contribution of this study is that it has identified a framework which describes the main categories or ideal types of firm motives for sponsoring sports events. Considering the (general) level of findings, described through the SMM-framework, we must see and interpret the practical managerial implications on the basis of these facts. Though the categories of motives in the SMM framework are at a general level, they do have implications for practice.
Arthur et al. (1998: 50) state that, "any organization should ... investigate whether or not they should actually become a sponsor". The SMM framework (Figure 2) can be a valuable tool in such investigation and decisions about whether or not participate in sponsorship. Moreover, the SMM framework provides one way of answering the questions related to cooperation and implementation of sponsorship programmes by Cornwall and Kwak (2015: 133): "How is it possible to work ... for the best outcomes ..?" Consequently, the framework can be useful for all partners involved when striving to make a sponsorship programme become as effective and successful as possible.

The SMM framework in figure 2 can be a useful and valuable toolkit for the identification of fundamental and critical factors that cooperating partners must define, analyse and decide to develop an appropriate strategy and tactics to meet expectations related to the sponsorship programme. It is reasonable to assume that depending on whether the firm's sponsorship motive can be categorised as a "market," "society," "bond," or "clan" motive, or a combination of some of these, there are significant differences in how the strategy and tactics are performed depending on the type of underlying sponsorship motive. On the basis of the four motivational categories, Table 4 suggests a general "guiding list" of ten practical steps of important areas of assessment that sponsor firm and event managers should consider when they cooperate in the development and performing a sponsorship programme.

On the basis of the four motivational categories in the SMM framework, Table 4 shows the areas of assessment that both firm and event managers must consider and incorporate in the planning process to meet the desired sponsorship motive profile of the firm. Table 4 urges managers to include consideration about both primary and secondary motives of the firm's sponsorship. Moreover, it suggests that the necessary actions must be performed and linked to achieve the specific objective(s) or goal(s) and evaluated according to its effectiveness. 
Table 4. General decision areas founded in the SMM framework

\begin{tabular}{|c|c|c|c|c|c|}
\hline Step & $\begin{array}{c}\text { Assessment areas developing a sponsorship } \\
\text { program }\end{array}$ & Market & Society & Clan & Bond \\
\hline 1. & $\begin{array}{l}\text { Decision about which of the four motivational categories } \\
\text { the sponsorship programme should be placed }\end{array}$ & & & & \\
\hline 2. & $\begin{array}{l}\text { Determination of order on the basis of the four } \\
\text { motivational categories (primary and secondary } \\
\text { motives) }\end{array}$ & & & & \\
\hline 3. & $\begin{array}{l}\text { Definition of the target group for the primary and } \\
\text { secondary motives for sponsoring the sports event }\end{array}$ & & & & \\
\hline 4. & $\begin{array}{l}\text { Statement of concrete and specific objective(s) or } \\
\text { goal(s) related to specific target group within the } \\
\text { primary and secondary sponsorship motives }\end{array}$ & & & & \\
\hline 5. & $\begin{array}{l}\text { Specification of area for actions and the associated } \\
\text { activities }\end{array}$ & & & & \\
\hline 6. & $\begin{array}{l}\text { Identification of resources required and needed } \\
\text { (internally and/or externally) }\end{array}$ & & & & \\
\hline 7. & $\begin{array}{l}\text { Identification of qualifications and recruitment of people } \\
\text { responsible for implementation }\end{array}$ & & & & \\
\hline 8. & $\begin{array}{l}\text { Timetable that specifies when to initiate sponsorship } \\
\text { activities and when these activities should end }\end{array}$ & & & & \\
\hline 9. & Clarification of degree of goal-achievement & & & & \\
\hline 10. & $\begin{array}{l}\text { Evaluation and consideration of effectiveness and } \\
\text { adjustment }\end{array}$ & & & & \\
\hline
\end{tabular}

In principle, steps one to ten in Table 4 is a linear process, where the next step (e.g. step four) comes as a natural, logical outcome of the previous one (e.g. step three). While Table 4 presents these steps in a natural order, following the working flow of partners involved in the sponsorship programme, it is likely that in reality it will be an iterative process between several (and maybe between all) steps. Accordingly, all steps in the table could also constitute and form a circular process where assessment areas, in for example step ten, are used as an input for the assessment in step one and so forth. Consequently, all aspects in Table 4 closely connect with each other in a natural flow and in a logical way, guided by the insights of the SMM framework.

The first two steps in Table 4 are a starting point in for developing a sponsorship programme. Using the SMM framework (in Figure 2) as a toolkit, the involved partners can systematically and openly discuss the advantages and disadvantages of each of the four motivational categories for sponsoring a sport event. Using this procedure, the involved partners can learn from and with each other about which of the four categories in the SMM framework are relevant and interesting to consider. This approach, then, can help them to form a common mindset about the possible overall sponsorship motive(s). There are two important outcomes of step one and two in Table 4. First, the partners must together decide whether they wish to focus on one or several motives for sponsorship. Secondly, the involved partners must together agree on which should be the firm's primary and secondary motives of firm sponsorship (e.g., the firm's primary motive is "market," and the secondary motive is "clan"). Consequently, using the SMM framework as a toolkit, the first two steps in Table 4 can help the partners to have a good overview of the four fundamental orientations namely, "market," "society," "bond," or "clan" motives - and, more importantly, to decide which of the four they best fit for their participation in sports sponsorship. Steps one and two provide a solid platform, direction and input for the assessment areas further along the process (mentioned in Table 4) and an increased focus of the preparatory work when planning and developing a sponsorship programme. 
The Sponsorship Motive Matrix (SMM): A Framework for Categorising Firms' Motives for Sponsoring Sports Events.

Skildum-Reid and Grey (2014: 24) state that, "realistically, no event will appeal to everyone". An implication of this is the importance of choosing the right target for the firm sport sponsorship. Steps three and four in Table 4 focus on these assessments. Specifically, step three defines the specific target group within both the primary and secondary categories of firm sponsorship motive according to the SMM framework. On this basis, they can set up specific objectives or goals related to the chosen target groups. Collett and Fenton (2011: 97) stress the importance of setting appropriate objectives by stating, "objectives are critical to understanding the impact of sponsorship investment". To overcome this obstacle the authors suggest that firm should establish what they call "SMART" objectives for sponsorship: 1) Specific, 2) Measurable 3) Achievable 4) Relevant and 5) Time bound. Consequently, when managers set SMART objectives properly, it become easier to perform steps nine and ten in Table 4, addressing goalachievement and assessment of the effectiveness of the sports sponsorship.

Steps five to eight in Table 4 connect to set standards that enable the fulfilment of the previous specific objectives for each of the specific target group(s) within the category suggested by the SMM framework. These are focused on the three W's - "what", "who" and "when" - aspects of sponsorship planning. Specifically the "whats" are related to elements that should constitute the actual practical actions involving the implementation of the sport sponsorship programme. Furthermore, the "whos" (steps six and seven) are about (i) ensuring having the resources available actually to perform the suggested practical actions and objectives, and (ii) ensuring that the resources have the right quality. According to Collett and Fenton (2011: 73) "there are three main resource groups to take into consideration: financial, physical and human". Though all three resources must be assessed, the quality of the last mentioned should be especially emphasised. Table 4 explicitly mentions this (step seven), prompting the identification of the necessary qualifications and the recruitment of people (internally or external, or both) responsible for implementing the sponsorship programme. Regardless of whether the sponsorship programme falls within "market," "society," "bond," or "clan" firm motive(s), all four domain have in one thing in common, the people who actually perform the specific sponsorship activities. You can create and plan the most perfect sponsorship programme, but it takes people to turn these ideas into real actions. To overcome possible obstacles related to the human aspects and to be effective, it is necessary for managers not to limit their recruitment to people having the necessary skills and knowledge: they should also recruit people who have the commitment and passion, as well as the ability to act flexibly throughout the course of the sponsorship programme. Consequently, among other qualities, the level of creative ability of potential candidates is one quality managers should consider in during recruitment. Recently, the literature has suggested creativity as an important and desirable human quality in order for organisations to come up with novel, useful and advantageous ideas that can be implemented into action (c.f. Slåtten and Mehmetoglu, 2015a). Clearly, as Collett and Fenton (2011: 75) nicely state it, "people are really important in making a sponsorship happen, and the challenge for the sponsorship team is to draw on the range of human resources available both internally and externally".

Séguin et al. (2005: 73) state that "many companies simply do not evaluate or have not found a practical way to measure the effectiveness of sponsorship programmes". It may appear difficult to evaluate the effect of sponsorship, but the last two steps in Table 4 (steps 9 and ten) remind managers to make these assessments. Fortunato (2013: 172) supports this view by stating that, "evaluation is one of the most difficult aspects of the sponsorship process, although it importance cannot be understated". A consequence of this complexity of causes and effects of sponsorship, it is advisable to take a broad approach in the evaluation of the effectiveness of sponsorship. Such an evaluation could include either quantitative or qualitative methods or both. Depending on the specific objectives or goals stated related to its overall motive domain in SMM framework, one or more methods could be chosen to identify and clarify 
the level of effectiveness. For example, in order to clarify degree of goal-achievement according to the "market" motive domain, one could use such quantitative methods as $\mathrm{ROI}$ or return on objectives (ROO), like units sold, as two ways of evaluating sponsorship effectiveness. Moreover, to identify the degree of effectiveness related to objectives or goals according to the "clan" motive domain, one could combine quantitative methods focusing on such factors as employee engagement, perception of firm culture and climate and combine these with qualitative methods, interviews with employees with focus-group techniques and personal interviews. One important aspect for managers to focus on with respect to the "clan" domain motive is whether the sponsorship programme is able to increase employees' perceptions of their deliverance of service quality both internally (e.g., other employees) or externally (e.g., firm customers), or both, and how this relates to employee turnover intentions. Research has revealed that employee perceptions of service quality relates to employee turnover intentions (Slåtten et al., 2011). Regardless of the choice and number of evaluation methods and techniques used, they must be considered according to their specific ability to contribute to conclusions of whether the sponsorship programme was within the zone of tolerance or not. Only by bringing these facts on table (referring to step ten in Table 4) can the necessary adjustments and developments be made for the improvement of future sponsorship programme. Consequently, investment in time and resources used to clarify goal-achievement and sponsorship effectiveness are both necessary and worth the effort. As Fortunato (2013: 180) states, "these investments in evaluation can impact planning and more efficient sponsorships can be the result".

General decisions areas in Table 4, founded on the SMM framework, has the potential to be an effective guiding tool that can ensure that sponsorship programmes are executed in a satisfactory and successful manner. Consequently, the SMM framework can contribute to achieving the objective stated by Kotler and Keller (2009: 561) of "designing the optimal sponsorship program" and simultaneously give sponsorship partners suggestions about "how... to work ... for the best outcomes" (Cornwall and Kwak, 2015: 133).

\section{Conclusions and Future Research}

This study makes a contribution to addressing the lacuna in the literature related to sponsorship. (Apostolopoulou and Papadimitriou, 2004; Cornwall and Kwak, 2015; Madhill and O'Reilly, 2010; Shank, 2009; Smith et al., 2016). Previous research on sponsorship has primarily taken a customer perspective. Consequently, the firm perspective and motivation for sponsoring sports events have been neglected (Slåtten et al., 2014a; Smith et al., 2016).

This study has taken a firm perspective. Specifically, the study has identified possible motivational categories related to firms' decisions about sponsorship, using sports events as the empirical context. On the basis of literature review, we devised a conceptual framework. The empirical study ended up with a final framework labelled as the Sponsorship Motive Matrix (SMM). It proposes four main categories of motives for sponsoring sport events which depend on the underlying motivational contrasts related to firms' decisions about sponsorship. The four motivational categories are (i) market, (ii) society, (iii) bond and (iv) clan.

Like most studies, there are a number of limitations in this study. We suggest future research using the SMM framework in the following four areas.

First, it is important to note that this is the first study that has explored and described a conceptual framework for categorising firm motives for sponsorship. Clearly, more research is needed to validate and test the suggested SMM framework more extensively. The findings reveal that the SMM framework covers the different motives for sponsorship of sports event well. However, sports sponsorship is only one of several types of sponsorship. There are also other forms of sponsorship, such as cultural sponsorship (e.g., art and music), socio-sponsorship (sponsorship of humanitarian organisations), event sponsorship (e.g., festivals and events) and media 
The Sponsorship Motive Matrix (SMM): A Framework for Categorising Firms' Motives for Sponsoring Sports Events.

sponsorship (e.g., firms paying for the production of a TV programme). Future research should test the SMM framework in other contexts of sponsorship and should reveal whether the suggested categories in the SMM framework are suitable for capturing firm motives for these other types of sponsorship.

Secondly, this study proposes a sponsorship motive profile that includes the specific primary and secondary motives. Although these are interesting and important findings, it would be valuable to have more in-depth understanding of the actual decision processes involved in sponsorship. How do decision processes about sponsorship normally take place? Who is involved in the process, and in what way do participants agree about what sports events the firm should sponsor? What factors are evaluated and emphasised both during the process and in the final decision about sponsorship? Following this study, future research could examine whether there is a link between firms' overall vision, marketing strategy, HRM strategy and other strategies, and the categories of sponsorship motives in the SMM framework. For example, do HRM strategies more closely relate to clan motives? Are marketing strategies linked to market motives? Studies of this nature, either qualitative or quantitative, would make valuable contributions and would deepen our understanding of firms' decision processes concerning sponsorship.

Thirdly, the findings of this study summarised in Table 2 suggest a difference in the pattern of motives between firms that have natural versus non-natural linkages between their products and the sports events they sponsor. It seems that for those firms with natural, logical linkages, the market motives are primary, whereas those with non-natural linkages have a more mixed constellation of primary motives such as market, society, and bond motives. Moreover, the findings indicate more clan motives among those firms that have nonnatural linkages compared with firms that have natural linkages between their products and the sponsored event. These findings are clearly interesting in themselves. However, this study used a qualitative methodology with eight key informants. Though this is satisfactory from a qualitative-methodology perspective, it is less satisfactory in respect of reliability and generalisability. Consequently, future research should test the SMM framework with a larger survey study that includes several key informants from a variety of sponsors. As part of this research work, there is a need to develop a reliable and valid measurement instrument that can capture the different indicators or facets of the four categories in the SMM framework. Such studies would confirm or disconfirm the tendency revealed in this study for a diversity of motives that depend on the linkage between product and event.

Fourthly, much of the sponsorship literature states that sponsorship is an effective tool for firms (Bowdin et al., 2011; Collett and Fenton, 2011; Walraven et al., 2012). Kotler and Keller (2009: 561) suggest that effective sponsorship requires firms "choosing the appropriate events; designing the optimal sponsorship program, and measuring the effects of sponsorship". However, our understanding of sponsorship effectiveness remains limited. In an article by Alexandris, Tsiotsou and James (2012: 363), the authors state that the "use of variables to assess sponsorship effectiveness is still at an early stage". In this area there is particular a need for more research that explores the effect or impact of sponsorship on employees. In a recent article of Edwards $(2015: 2)$ the author state that "a gap...exists...regarding knowledge of the impact of that the sponsorship of major sporting events has on employee". Consequently, future research should look into and explore factors that contribute to effective sponsorship related to sponsor firm's employees. Are there some sponsorship factors that can be labelled universal, leading to effective sponsorship independent of type (e.g., cultural sponsorship or event sponsorship), such as characteristics of firms or types of motives? Future research could use the SMM to study effectiveness in a variety of ways. Here we suggest four possibilities for future research to investigate. First, it would be interesting to compare effectiveness, manifested in overall effect variables such as cognitive and affective satisfaction or aspects related to employee emotions (for the latter ideas see Slătten, 2011), across all four types of firm motives for 
sponsorship. Secondly, another possible topic is to study the effectiveness of only one type of motive, for example, the effectiveness of the bond motive on dimensions such as employee ownership, relationship quality, trust, or switching intention. Thirdly, research could study the effectiveness of the clan motive in relation to outcome variables such as quality of life, job satisfaction, employee-perceived service quality, customer perceptions of quality, customer satisfaction or customer loyalty. For example, it would be interesting to explore how clan motive is linked to important aspect such as job engagement and/or innovative behaviour, which has been proposed as $s$ new and fresh upcoming perspective in human resource management (see Slåtten and Mehmetoglu, 2015b). Fourthly, research could study the effectiveness of mixes of primary and secondary firm motives. Are some mixes of motives more effective than others? Or does sponsorship effectiveness encompass all four types of motives, suggesting that firm sponsorship should lie somewhere close the middle of the SMM framework? These and other research possibilities, using the SMM framework, would extend and deepen our understanding of what makes sponsorship effective, help firms to make sound decisions about sponsorship and help firm managers and event managers to "design the optimal sponsorship program" (Kotler and Keller, 2009: 561).

\section{References}

Apostolopoulou, A., D. Papadimitriou (2004) "Welcome Home": Motivations and Objectives of the 2004 Grand National Olympic Sponsors. Sport Marketing Quarterly 13 (4), 180-192.

Alexandris, K., H. R. Tsiotsou, J. James (2012) Testing a Hierarchy of Effects Model of Sponsorship Effectiveness. Journal of Sport Management 26 (5), 363-378.

Arthur, D., D. Scott, T. Woods (1997) A conceptual model of the corporate decision making process of sport sponsorship acquisition. Journal of Sport Management 11 (3), 223-233.

Arthur, D., D. Scott, T. Woods, R. Booker (1998) Sport sponsorship. A Process model for the effective implementation and management of sport sponsorship programs. Sport Marketing Quarterly 7 (4), 49-60.

Bhat, S. (2012) The effect on sponsoring brands of attitude toward a sponsored event and brand-event fit. San Francisco State University. NC1102 (1). URL: http: //www.aabri.com/NC2011Manuscripts/N C11012.pdf (Accessed on 14.05.2016)

Bickman, L., D. J. Rog (1998) Handbook of Applied Social Research Methods. Thousand Oaks, CA: Sage Publications.

Bouchet, A., T. W. Doellman, M. Troilo, B. R. Walkup (2015) The Impact of International Football Matches on Primary Sponsors and Shareholder Wealth. Journal of Sport Management 29, 200-210.

Bowdin, G., J. Allen, W. O'Toole, R. Harris, I. McDonnell (2011) Events Management. 3rd ed. Abingdon, UK: Routledge.

Bryman, A. (1988) Quantity and Quality in Social Research. London: Routledge.

Cameron, N. (2009) Understanding sponsorship and its measurement implications. Journal of Sponsorship 2 (2), 131-139.

Clark, J., T Lachowetz, R. L. Irwin, K. Schimmel (2003) Business-to-Business Relationships and Sport: Using Sponsorship as a Critical Sales Event. International Journal of Sports Marketing \& Sponsorship 5 (2), 129-144.

Collett, P., W. Fenton (2011) The Sponsorship Handbook: Essential Tools, Tips and Techniques for Sponsorship and Sponsorship Seekers. San Francisco: Jossey-Bass.

Cornwell, T. B., D. H. Kwak (2015) Sponsorship-Linked Marketing: Introduction to Topics. Journal of Sport Management 29, 133-136.

Cornwell, T. B., I. Maignan (1998) An International Review of Sponsorship Research. Journal of Advertising 27 (1), 1-21.

Cornwell, T. B. (1995) Sponsorship-linked marketing development. Sport Marketing Quarterly 4 (4), 13-24.

Cornwell, T. B., M. S. Humphreys, A. M. Maguire, C. S. Weeks, C. L. Tellegen (2006) Sponsorship-Linked Marketing: The Role of Articulation in Memory. Journal of Consumer Research 33 (3), 312-321. 
The Sponsorship Motive Matrix (SMM): A Framework for Categorising Firms' Motives for Sponsoring Sports Events.

Crompton, J. L. (2004) Conceptualization and alternate operationalization of the measurement of sponsorship effectiveness in sport. Leisure studies, 23 (3), 267-281.

Davis, F., G. Tsiantas (2008) Selection of leveraging strategies by national Olympic sponsors: A proposed model. International Journal of Sports Marketing \& Sponsorship 9 (4), 271-289.

Delia, E. B., C. G. Armstrong (2015) \#Sponsoring the \#FrenchOpen: An examination of Social Media Buzz and Sentiment. Journal of Sport Management, 29, 184-199.

Edwards, M.R. (2015) The Olympic Effect: Employee reactions to their employer's sponsorship of a high-profile global sporting event. Human Resource Management, 1-13.

Fortunato, J. A. (2013) Sport sponsorship: principles and practices. Jefferson, NC: McFarland \& Company.

Gardner, M., P. Shuman (1988) Sponsorships and small businesses. Journal of Small Business Management 26 (4), 44-52.

Greenhalgh G., C. T. Greenwell (2013) What's in It for Me? An Investigation of North American Professional Niche Sport Sponsorship Objectives. Sport Marketing Quarterly 22 (2), 101-112.

Grönroos, C. (2007) Service Management and Marketing: Customer Management in Service. 3rd ed. Chichester: John Wiley.

Gwinner, K., G. Bennett (2008) The Impact of Brand Cohesiveness and Sport Identification on Brand Fit in a Sponsorship Context. Journal of Sport Management 22, 410-426.

Harvey, B. (2001) Measuring the Effects of Sponsorship. Journal of Advertising Research 41 (1), 59-65

Helgesen, T. (2004) Markedskommunikasjon: Prinsipper for effektiv informasjon og påvirkning [Marketing communication: Principles for effective information and influence]. 6th ed. Oslo: Cappelen Akademiske forlag.

Hickman, T. M., K. E. Lawrence, J. C. Ward (2005) A social identities perspective on the effect of corporate sport sponsorship on employees. Sport Marketing Quarterly 14 (3), 148-157.
Jiffer, M., M. Roos. (1999) Sponsorship: A way of communicating. Stockholm: Ekerlids Forlag.

Kotler, P., K. L. Keller (2009) Marketing Management. 13th ed. Upper Saddle River, N.J.: Pearson/Prentice Hall.

Kvale, S., S. Brinkmann (2009) Det kvalitative forskningsintervju [The qualitative research interview]. 2nd ed. Oslo: Gyldendal Akademisk.

Madhill, J., N. O'Reilly (2010) Investigating social marketing sponsorships: Terminology, stakeholders, and objectives. Journal of Business Research 63 (2), 133-139.

McAllister, M. P. (1998) College bowl sponsorship and the increased commercialization of amateur sports. Critical Studies in Mass Communication 15 (4), 357-381.

Meenaghan, J. A. (1983) Commercial Sponsorship. European Journal of Marketing 17 (7), 5-73.

Meenaghan, T. (2001) Understanding sponsorship effects. Psychology and Marketing 18 (2), 95-122.

Meenaghan, T. (1991) The Role of Sponsorship in the Marketing Communications Mix. International Journal of Advertising 10 (1), 35-47.

Miloch, K., K. Lambrecht (2006) Consumer awareness of sponsorship at grassroots sport events. Sport Marketing Quarterly 15 (3), 147-154.

Mullin, B. J., S. Hardy, W. A. Sutton (2000) Sport marketing. 2nd ed. Champaign, IL: Human Kinetics.

Nagel, T. (1970) The Possibility of Altruism. Oxford: Clarendon Press.

Ngan, H. M. K., G. P. Prendergast, A. S. L. Tsang (2011) Linking sports sponsorship with purchase intentions: Team performance, stars, and the moderating role of team identification. European Journal of Marketing 45 (4), 551-566.

Nielsen, O. (1990) Sponsering $i$ virksomhedens markedsføring [Sponsoring in the company's marketing]. København: Handelshøjskolens Forlag.

Okasha, S. (2005) Altruism, group selection and correlated interaction. British Journal for the Philosophy of Science 56 (4), 703-725. 
Palmatier, R. W., C. B. Jarvis, J. R. Bechkoff, F. R. Kardes (2009) The Role of Customer Gratitude in Relationship Marketing. Journal of Marketing 73 (5), 1-18.

Plewa, C., P. G. Quester (2011) Sponsorship and CSR: is there a link? A conceptual framework. International Journal of Sports Marketing and Sponsorship 12 (4), 22-48.

Polonsky, M. J., R. Speed (2001) Linking sponsorship and cause related marketing. European Journal of Marketing 35 (11/12), 1361-1389.

Rifon, N. J., S. M. Choi, C. S. Trimble, H. Li (2004) Congruence Effects in Sponsorship: The Mediating Role of Sponsor Credibility and Consumer Attributions of Sponsor Motive. Journal of Advertising 33 (1), 30-42.

Rosenberg, M. R., K. P. Woods (1995) Event sponsorship can bring kudos and recognition. Bank Marketing 27 (5), 13-18.

Samuelsen, B. M., A. Peretz, L. E. Olsen (2010) Merkevareledelse på norsk 2.0 [Brand Management in Norwegian 2.0]. Oslo: Cappelen Damm.

Sandler, D.M., D. Shani (1989) Olympic sponsorship vs "ambush" marketing: Who gets the gold? Journal of Advertising Research, 29 (4), 9-14.

Schulze, W. S., M. H. Lubatkin, R. N. Dino (2002) Altruism, Agency, and the Competiveness of Family Firms. Managerial and Decision Economics 23 (4/5), 247-259.

Séguin B., K. Teed, N. J. O'Reilly (2005) National sports organizations and sponsorships: an identification of best practices. International Journal of Sport Management and Marketing 1 (1/2), 6992.

Shank, M. D. (2001) Sports Marketing: A strategic perspective. 2nd ed. Upper Saddle River, N.J.: Pearson/Prentice Hall.

Shank, M. D. (2009) Sports Marketing: A strategic Perspective. 4th ed. Upper Saddle River, N.J.: Pearson/Prentice Hall.

Shone, A., B. Parry (2004) Successful Event Management: A Practical Handbook. 2nd ed. London: Thomson Learning.
Silverman, D. (2000) Doing Qualitative Research. London: Sage.

Sirgy, M. J., D. J. Lee, J. S. Johar, J. Tidwell (2008) Effect of self-congruity with sponsorship on brand loyalty. Journal of Business Research 61 (10), 1091-1097.

Skildum-Reid, K. and Grey, A.M. (2014) The Sponsorship Seekers Toolkit, McGrawHill, $4^{\text {th }}$ edition.

Skinner, B. E., V. Rukavina (2003) Event Sponsorship. Hoboken, N. J.: John Wiley and Sons.

Sleight, S. (1989). Sponsorship: What It Is and How to Use It. London: McGraw-Hill.

Slåtten, T., M. Mehmetoglu (2015a) The effects of transformational leadership and perceived creativity on innovation behaviour in the Hospitality industry. Journal of Human resources in Hospitality and Tourism 14 (2), 195-219.

Slåtten, T., M. Mehmetoglu (2015b) "Antecedents and effects of engaged frontline employees: A study from the hospitality industry". In Emerald Gems book titled: New Perspectives in Employee Engagement in Human Resources. Publisher: Emerald Group Publishing Limited.

Slåtten, T., B. R. Matovu, S. Connolley (2014a) Four drivers of effective sponsorship: $A$ case study of the Birkebeiner race in Norway. Journal of Convention \& Event Tourism 15 (3), 220-235.

Slåtten, T. (2014) Determinants and effects of employee's creative self-efficacy on innovative activities. International Journal of Quality and Service Sciences 6 (4), 326-347.

Slåtten T., G. Svensson, S. Sværi (2011) Service Quality and Turnover Intentions as perceived by Employees: Antecedents and Consequences. Personnel Review 40 (2), 205-221.

Slåtten, T. (2011). Antecedents and effects of employee's feelings of joy on employee innovative behavior. International Journal of Quality and Service Sciences, 3(1), 93-109.

Smith, W.W., R.E. Pitts, S.W. Litvin, R.W. Mack (2016) It's got to "fit" - exploring sponsorship decisions for festival. International Journal of Hospitality and Event Management, X, 1-12. 
The Sponsorship Motive Matrix (SMM): A Framework for Categorising Firms' Motives for Sponsoring Sports Events.

Smith, B. (1998) Buyer-Seller Relationships: Bonds, Relationship Management, and Sex-type. Canadian Journal of Administrative Sciences 15 (1), 76-92.

Speed, R., P. Thompson (2000) Determinants of sports sponsorship response. Journal of the Academy of Marketing Science 28 (2), 226-238.

Thjømøe, H. M. (2010) Sponsing: Forretning eller lek med penger [Sponsorship: Business or playing with money]. Magma, Econas Tidsskrift for Økonomi og Ledelse 1. https://www. magma. no/sponsing-forretning-eller-lek-medpenger (Accessed on 14.05.2016)

Ukman, L. (1995). The IEG's complete guide to sponsorship: Everything you need to know about sports, arts, events, entertainment, and cause marketing. Chicago: International Events Group Inc.

Walraven, M., R. H. Koning, M. van Bottenburg (2012) The effects of sports sponsorship: A review and research agenda. The Marketing Review 12 (1), 17-38.

Williamson, O. E. (1975) Markets and hierarchies: analysis and antitrust implications: a study in the economics of internal organization. New York: The Free Press.

Zinger, J.T., N.J. O`Reilly (2010). An examination of sports sponsorship from a small business perspective. International Journal of Sports Marketing and Sponsorship 11 (4), 283-301. 